\title{
Gabrova pepelovka, Erysiphe arcuata
}

\section{Tine HAUPTMAN}

Gabrovo pepelovko povzroča gliva Erysiphe arcuata. Bolezen domnevno izvira iz V Azije, natančneje iz Japonske, v zadnjih nekaj letih pa se pojavlja tudi na belih gabrih (Carpinus betulus) v Evropi. Pri nas je bila prvič določena leta 2007, pojavlja pa se tako na urbanem drevju, živih mejah kot tudi v gozdu. Natančno razširjenost kot tudi škodljivost te nove pepelovke pri nas še ugotavljamo.

Gliva na listih gostitelja oblikuje podgobje (micelij), ki je vidno kot belo-siva prevleka (slika 1). Opažamo, da je micelij najbolje viden spomladi, ko gliva oblikuje trosonosce (slika 3), ki oblikujejo konidije, kasneje pa postane slabo opazen (nekoliko bolje se micelij vidi, če okužen list pogledamo od strani). Vseeno pa na mestih, kjer se je spomladi pojavil micelij ostanejo klorotične lise (slika 2), ki so drugi značilni simptom te bolezni. Gliva liste oslabi (liste lahko predvsem jeseni dodatno okuži tudi gliva Apiosporopsis

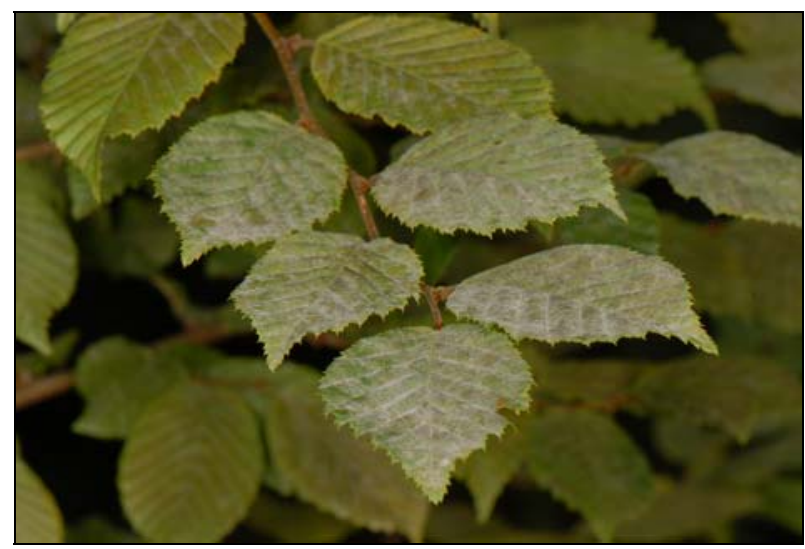

Slika 1: Micelij glive Erysiphe arcuata na listih belega gabra

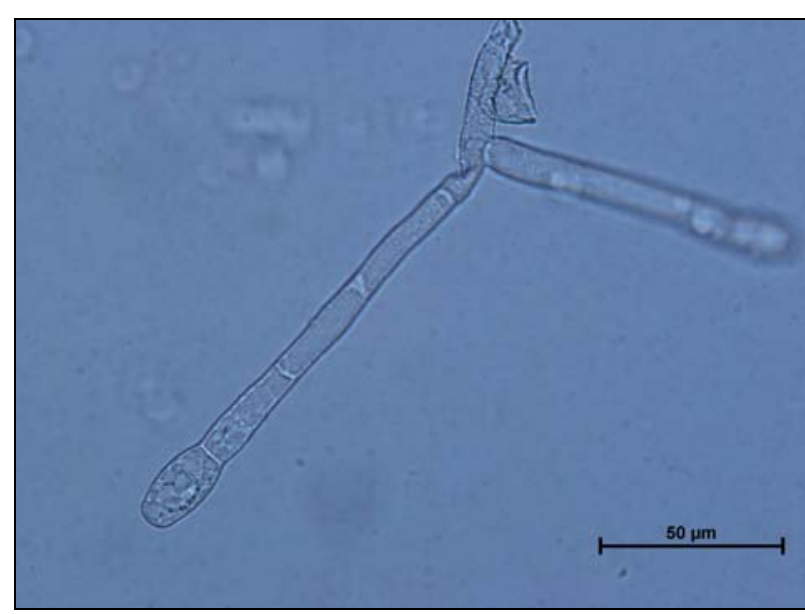

Slika 3: Trosonosec (konidiofor) na katerem nastajajo konidiji carpinea, ki povzroča rjavenje gabrovih listov) zato se obarvajo rumeno in lahko predčasno odpadejo. Pozno poleti in jeseni gliva oblikuje še spolno obliko trosišč (teleomorf) - kleistotecije, ki so na listih opazni kot majhne črne pikice. V kleistotecijih (slika 4), ki imajo posebne priveske, nastajajo aski $\mathrm{z}$ askosporami, ki spomladi služijo za primarno okužbo novih listov. Drug bolj pogost način okužbe pa je s hifami glive, ki prezimijo v brstih gostitelja.

Različne vrste pepelovk večinoma malo prizadenejo svoje gostitelje, nekatere pa so prinešene iz drugih kontinentov in lahko povzročajo večje poškodbe gostiteljev. Zato bi bilo ustrezno natančno opazovati okužene bele gabre in poročati o prezgodnjem odpadanju listja, če se bo le-to pojavilo. V tem primeru prosimo za vzorec prezgodaj odpadlih listov, da bomo gabrovo pepelovko določili z mikroskopiranjem.

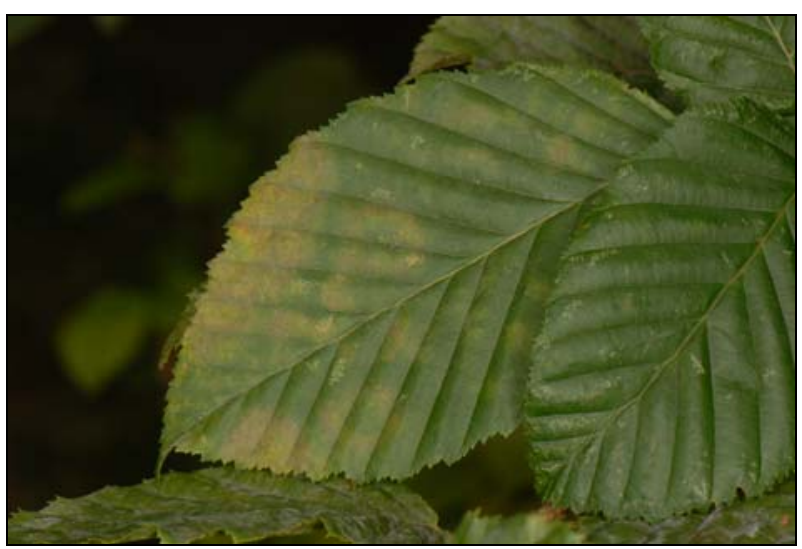

Slika 2: Klorotične lise na listih gabra

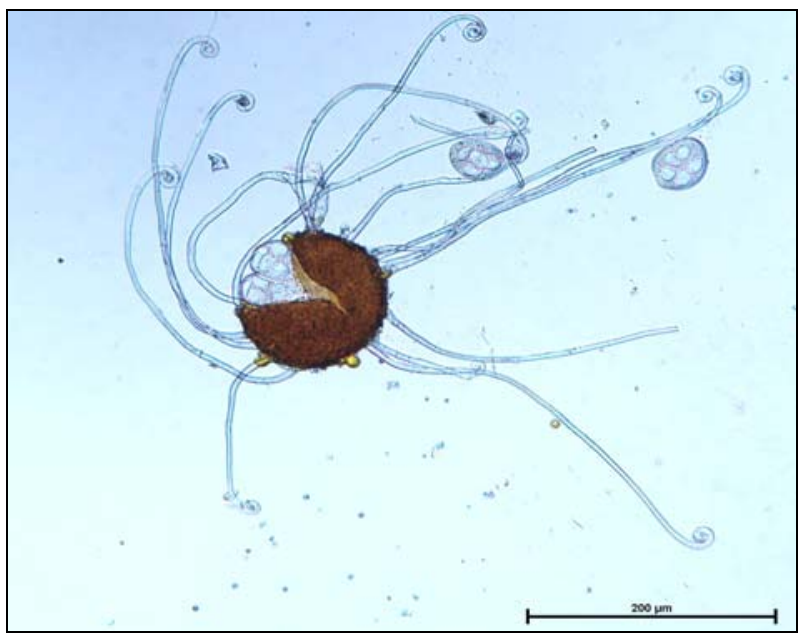

Slika 4: Kleistotecij s priveski iz katerega izhajajo aski z askosporami 